\title{
Effectiveness of Liquid Waste Management in Plywood Industry in South Kalimantan
}

\author{
Dr. Ir. Hj. Darni Subari, MS \\ Faculty of Forestry Science, Lambung Mangkurat University, Indonesia
}

\begin{abstract}
The purpose of this study was to find out the effectiveness of liquid waste treatment and the efficiency of the decrease in pollution level at the treatment of liquid waste from plywood industry. The study was conducted in 3 (three) plywood industries in South Kalimantan. The results showed that the liquid waste from the washing of glue mixer and glue spreader had very low quality even lower than the water quality of Barito River or Martapura River; therefore, if not treated accordingly it will cause pollution in waterbodies. The results of the waste analysis at inlet and outlet indicated that the efficiency of WWTP in the plywood industries was high at $67 \%$ to $99 \%$, with the water discharge $0.007 \mathrm{~m}^{3} / \mathrm{m}^{3}$ of product. On the basis of the Degree of South Kalimantan Governor No. 036 of 2008, the maximum discharge is $0.30 \mathrm{~m}^{3} / \mathrm{m}^{3}$ of product in order to meet the quality standards. Sludge at WWTP can be used as a mixture of adhesive (filler).
\end{abstract}

Keywords: liquid waste, pollutant

\section{Introduction}

1.1. Industrial Waste, Pollution, and Environmental Quality Standards Waste from Plywood Industry

In the manufacturing of plywood the waste is unavoidable. According to Sarajar (1989), the waste from wood processing can be divided into two types, namely the waste from primary wood processing and the waste from secondary wood processing. The waste from the primary wood processing is resulted from sawmill industry, plywood industry and pulp and paper industry while the waste from plywood industry can be in the forms of core, spur trim, round up, clipping, trimming, sawdust, sander dust. In general, the waste from plywood industry is $57 \%$ (Widarmana, 1984).

Almost all parts of the process of plywood production contribute to the production of waste with the difference in number and characteristics (Mintarsih et al. 2006). Types and sources of waste from plywood industry include:

\section{Solid waste}

The solid waste generated by plywood industry almost exists on each machine so that its quantity is very large, reaching 40 percent of the volume of incoming logs. The high percentage of solid waste in the production process requires each plywood company to utilize the solid waste optimally. The solid waste generated in the production of plywood includes log salvage, log end, sawdust, wood bark, edging, leftover peel, remaining pieces of log, remaining pieces of veneer, veneer which is not standard, remaining pieces of core, core reject, glue solids, glue spills, remaining pieces of side panel, slab, sander dust, residual sludge of WWTU (Waste Water Treatment Unit), boiler ash, packaging paper, film face, and polyester coating. The solid waste from plywood production is dominated with wood waste. In addition to the wood waste, there is domestic solid waste, which is the waste from the labor activities, because a plywood industry generally uses a large number of human resources. The domestic solid waste is in the form of paper, tissue and plastic.

Factors influencing the generation of solid waste produced by plywood industry (Mintarsih at el) : (a). The number and the condition of $\log$ for plywood production, (b). The processing methods and the number of wood waste remanufactured for further production.,(c). The production machines dan (d). The number of labors in plywood industry influencing the number of domestic solid waste.

\section{Liquid waste}

Liquid waste from plywood production is generally generated only from the washing process of the glue spreader machine and the washing process of other production equipment. This makes the composition of the liquid waste only consist of water and materials used in the manufacturing of adhesives. Based on its original source, namely glue spreader machine, the liquid waste contains materials corresponding to the type of adhesive used. For example, for the adhesive type of urea formaldehyde, its original source is ureaformaldehyde resin of industrial flour, kaolin, hardener, T-500, catcher, and bassilium. For the other types of adhesives, the difference is only on the resins used, namely melamine formaldehyde resin and phenol formaldehyde resin. However, in general the biggest composition or content of each adhesive is resin, reaching 
70 to 80 percent of the total adhesive mixture, while the rest are additional materials whose composition is different from each other. The characteristics of liquid waste from plywood industry are generally dominated by the value of pH, BOD (Biological Oxygen Demand), COD (Chemical Oxygen Demand), TSS, phenol, and total ammonia. Liquid waste treatment system will be determined by the parameters of the liquid waste generated. By knowing the types of the parameters in liquid waste, the treatment methods and the choice of the equipment types required for the treatment can be set.

In plywood industry, the factors which influence the generation of liquid waste are as follows (Anonim, 2010) : (a). Types of materials used in adhesive manufacturing, (b). Amount of water used in the washing process of equipment and production machines, (c). Change frequency of glue/ adhesive used ,(d). Production systems/processes used (dry/wet) dan (e). Number of employees in the plywood industry that will affect the amount of domestic waste water

\subsection{Pollution and Environmental Quality Standards}

Pollution is the introduction of living things, matter, energy and/or other components into the environment and/or the change of the environment order by human activities or natural processes, so that the quality of the environment decreases to a certain level causing the environment to be less or no longer to be able to function as intended (Act No.23 of 1997 on Environmental Quality Standards).

Basically the activity of an industry is to process input into output. The observation on the industrial pollutant sources can be implemented in the input, the process, and the output by considering the specifications and types of the waste. Pollution caused by the industry is resulted from the waste coming out of the factory and containing hazardous and toxic materials. Pollutants come out together with waste through the medium of air, water and soil which is the component of natural ecosystem. The waste that comes out of the factory and goes into the environment can be identified as a source of pollution, and as the source of pollution it is necessary to identify the types of pollutants released, along with their quantity and its exposure range (Kris, 2002).

The excessive use of water, the disposal systems that do not yet meet the quality standards, and less skilled employees are some of the factors to be considered in identifying the sources of pollution. In ecoefficiency, according to CPUU Unmul (2008), waste is part of Non Product Output. To prevent any environmental pollution by such various activities of plywood industries, it is necessary to control the environmental pollution by setting the environmental quality standards (kristato, 2002). Environmental quality standard are size limits or levels of living things, matter, energy, or components that exist or should exist and/or pollutant elements that are tolerable in a particular resource as the elements of the environment (Act No. 23 of 1997 on Environmental Management)

The determination of liquid waste quality standards is in accordance with the Decree of the Ministry of Environment No: Kep-51/Men LH/10/1995, about Liquid Waste Quality Standards for Industrial Activities, as presented in Table 1.

Table 1. Quality standards of liquid waste for plywood industry

\begin{tabular}{lcc}
\hline \multicolumn{1}{c}{ Parameter } & $\begin{array}{c}\text { Maximum Content } \\
(\mathrm{mg} / \mathrm{l})\end{array}$ & $\begin{array}{c}\text { Maximum Pollutant } \\
(\mathrm{mg} / \mathrm{l})\end{array}$ \\
\hline BOD & 75 & 22.5 \\
COD & 125 & 37.5 \\
TSS & 50 & 15 \\
Phenol & 0.25 & 0.08 \\
Total Ammonia (as N) & 4 & 12 \\
pH & $6.0-9.0$ & $6.0-9.0$ \\
\hline Maximum waste discharge & $0.30 \mathrm{~m}^{3} / \mathrm{m}^{3}$ of plywood production \\
\hline
\end{tabular}

Note:

1. The maximum level for each parameter in the table above is expressed in milligrams of parameter per liter of wastewater

2. The maximum pollution burden for each parameter in the table above is expressed in grams of parameter per $\mathrm{m}^{3}$ of plywood product

3. $1,000 \mathrm{~m}^{2}$ of product $=3.6 \mathrm{~m}^{3}$ of product with a thickness of 3.6 millimeters

Source : Decree of the Ministry of Environment No: Kep-51/MEN LH/10/1995

These liquid waste quality standards are reinforced by the Regulation of South Kalimantan Governor Number: 04 of 2007 on Liquid Waste Quality Standard for Industrial Activities of Hotels, Restaurants, Hospitals, Domestic and Mining. The liquid waste quality standards of plywood industry are shown in Table 2. 
Table 2. Quality standards of liquid waste for the plywood industry

\begin{tabular}{lcc}
\hline \multicolumn{1}{c}{ Parameter } & $\begin{array}{c}\text { Maximum Content } \\
(\mathrm{mg} / \mathrm{l})\end{array}$ & $\begin{array}{c}\text { Maximum Pollutant } \\
(\mathrm{mg} / \mathrm{l})\end{array}$ \\
\hline BOD & 75 & 22.5 \\
COD & 125 & 37.5 \\
TSS & 50 & 15 \\
Phenol & 0.25 & 0.08 \\
Total Ammonia (as N) & 4 & 12 \\
pH & $6.0-9.0$ & $6.0-9.0$ \\
\hline Maximum waste discharge & \multicolumn{2}{c}{$0.30 \mathrm{~m}^{3} /$ ton of plywood production } \\
\hline
\end{tabular}

Note:

1. The maximum level for each parameter in the table above presented in milligrams/liter of wastewater

2. The maximum pollution burden for each parameter in the table above is expressed in kilograms per ton of plywood products

3. $1,000 \mathrm{~m}^{2}$ of product $=3.6 \mathrm{~m}^{3}$ of products with a thickness of 3.6 millimeters

Source: Regulation of South Kalimantan Governor No. 036 of 2008

\section{Results And Discussion}

\subsection{Effectiveness of Liquid Waste Management Water Quality and Liquid Waste}

Liquid waste management in plywood company is performed centrally (on side) carried out with the system of Waste Water Treatment Plant (WWTP). Liquid waste generated from production activities is routed through the disposal network to Waste Water Treatment Plant (WWTP) as described previously. The liquid waste channeled into WWTP had the quality presented in Table 3.

Table 3. Liquid waste/effluent quality from inlet of plywood companies surveyed

\begin{tabular}{clcccc}
\hline \multirow{2}{*}{ No } & Parameter & $\begin{array}{c}\text { NAB } \\
(\mathrm{mg} / \mathrm{l})\end{array}$ & $\begin{array}{c}\text { PT. SST } \\
(\mathrm{mg} / \mathrm{l})\end{array}$ & $\begin{array}{c}\text { PT. WTU } \\
(\mathrm{mg} / \mathrm{l})\end{array}$ & $\begin{array}{c}\text { PT. BIC } \\
(\mathrm{mg} / \mathrm{l})\end{array}$ \\
\hline 1. & $\mathrm{pH}$ & - & 7.81 & 8.73 & 10.51 \\
2. & TSS & 50 & 104 & 113 & 241 \\
3. & BOD & 75 & 4,560 & 17,340 & 9.30 \\
4. & COD & 125 & 9,887 & 36,832 & 18,700 \\
5. & Ammoniac & 4 & 15,550 & 5,100 & 46,900 \\
6. & Total Phenol & 0.25 & 6,17 & 46.63 & 19.07 \\
\hline
\end{tabular}

Sources: - Observation in the field in 2011

- Decree of South Kalimantan Governor No. 036 of 2008

The results of the analysis of liquid waste from the three companies indicated that the inlet going into the tank contained pollutants and the liquid waste quality of all the plywood industries exceeded Threshold Limit Values (TLV). This liquid waste also had poorer quality than the surrounding waters (Barito River and Martapura River). The quality data is shown in Table 4.

Table 4. Quality of Barito River and Martapura River (at a point) near plywood industries

\begin{tabular}{|c|c|c|c|c|c|c|}
\hline \multirow{2}{*}{ No } & \multirow{2}{*}{ Parameter } & \multirow{2}{*}{$\begin{array}{l}\text { TLV } \\
(\mathrm{mg} /)\end{array}$} & \multicolumn{2}{|c|}{ Martapura River } & \multicolumn{2}{|c|}{ Barito River } \\
\hline & & & BLH & Observation & BLH & Observation \\
\hline 1. & $\mathrm{pH}$ & - & - & 7.74 & - & 7.53 \\
\hline 2. & TSS & 50 & 38 & 54 & 48 & 58 \\
\hline 3. & BOD & 2 & 10.5 & 14.4 & 6.24 & 7.2 \\
\hline 4. & COD & 10 & 21.26 & 31.53 & 14.45 & 14.31 \\
\hline 5. & Ammoniac & 0.5 & 0.19 & 0.16 & 0.95 & 0.28 \\
\hline 6. & Total Phenol & 0.001 & 0.01 & 0.44 & 0.03 & 0.26 \\
\hline
\end{tabular}

Sources: - Observation in the field (June 2011)

in Class I

- Decree of South Kalimantan Governor No. 05 of 2007 on Water Quality Standards of Rivers

- Final Report of BLH (Environment Agency) in 2010 (September-October)

Martapura is a tributary of Barito River. Along Martapura and Barito rivers are human settlement and industries of plywood, rubber and some other kinds. Martapura River, in accordance with the Regulation of South Kalimantan Governor No. 05 of 2007 on River Water Quality Standards, is included in Class I. Of the river water quality data it can be identified that Barito River and Martapura River have been polluted because almost all of the indicators observed in river water samples exceeded the threshold limit values as the water group of class I.

However, the quality of river water was still better than the liquid waste quality of the plywood industry; hence if the liquid waste is not treated accordingly, it will add to the pollution that occurred in the river water (waters around the plywood industries). Besides conducting the treatment at the Waste Water Treatment 
Plant (WWTP), a company also had the obligation to dispose the liquid waste after meeting the threshold limit values. The quality of effluent outlet had undergone the treatment process in all three plywood industries as shown in Table 5.

Table 5. Liquid waste/effluent quality of outlet in three plywood companies

\begin{tabular}{|c|c|c|c|c|c|}
\hline No & Parameter & $\begin{array}{c}\text { TLV } \\
(\mathrm{mg} /)\end{array}$ & $\begin{array}{c}\text { PT. SST } \\
(\mathrm{mg} / \mathrm{l})\end{array}$ & $\begin{array}{c}\text { PT. WTU } \\
(\mathrm{mg} / \mathrm{l})\end{array}$ & $\begin{array}{c}\text { PT. BIC } \\
(\mathrm{mg} / \mathrm{l})\end{array}$ \\
\hline 1. & $\mathrm{pH}$ & - & 7.8 & 8.26 & 8.12 \\
\hline 2. & TSS & 50 & 34 & 3.30 & 31 \\
\hline 3. & BOD & 75 & 18.6 & 7.35 & 24.6 \\
\hline 4. & COD & 125 & 38.43 & 30 & 52.13 \\
\hline 5. & Ammoniac & 4 & 0.26 & 0.08 & 0.15 \\
\hline 6. & Phenol & 0.25 & 0.16 & 0.25 & 0.12 \\
\hline
\end{tabular}

Sources: - Observation in the field (June 2011)

- Decree of South Kalimantan Governor No. 036 of 2008

The results of the waste water evaluation at the outlet, on the basis of the Regulation of South Kalimantan Governor No. 036 of 2008 on Liquid Waste Quality Standards, indicated that the industrial liquid waste of plywood industry still met the quality standards. Quantitatively, the plywood industries produced liquid waste $($ discharge $)=68.4 \mathrm{~m}^{3} /$ month in average. With an average production of $9,854.06 \mathrm{~m}^{3} / \mathrm{month}$, then the ratio of liquid waste : productivity was $68.4 \mathrm{~m}^{3}: 9,854.06 \mathrm{~m}^{3}=0.007 \mathrm{~m}^{3}$ per $\mathrm{m}^{3}$ of product. On the basis of the Decree of South Kalimantan Governor No. 036 of 2008, the maximum discharge is $0.30 \mathrm{~m}^{3}$ per $\mathrm{m}^{3}$ of product. It meets the quality standards.

\subsection{Evaluation and Discussion}

The calculation of the evaluation was conducted at the aeration pond of activated sludge of Waste Water Treatment Plant (WWTP) at three plywood industries studied, namely PT. WTU, PT. SST and PT. BIC in Banjarmasin. WWTP observed was the installation processing waste water (effluent) from the process of the glue mixer unit and glue spreader unit. The biological processes of waste decomposition of WWTP each had 3 parts of aeration ponds.

\subsection{Analysis of Waste Quality of WWTP}

\subsubsection{Decrease in concentration of BOD (Biological Oxygen Demand)}

Biological oxygen demand (BOD) is the amount of oxygen needed by the bacteria during the decomposition of organic compounds. In this case it can be interpreted that the organic compound is food for bacteria. BOD is used to determine the level of pollutants by organic compounds that can be broken down by bacteria. The results of laboratory tests indicated that there was a decrease in BOD concentration of waste measured at the inlet and outlet of WWTP. The values met the effluent quality standards for plywood industry in accordance with the Regulation of South Kalimantan Governor No. 036 of 2008 and the Decree of the Ministry of Environment No. Kep.51/ MENLH/10/1995, i.e. the maximum load is $150 \mathrm{mg} / \mathrm{l}$. The average value of the waste outlet at WWTP of PT. SST, PT. WTU, and PT. BIC was $18.6 \mathrm{mg} / 1,7.35 \mathrm{mg} / 1,24.6 \mathrm{mg} / \mathrm{l}$, respectively, as shown in Table 7.

The decrease in the concentration of BOD in the aeration ponds occurred because of the symbiotic relationship of metabolism between the organic load of pollutant waste and bacteria from the pond. In addition to the bacteria there were other factors that supported the process of decomposition of organic carbon contained in the waste, resulting in a decrease in the concentration of BOD in the aeration pond.

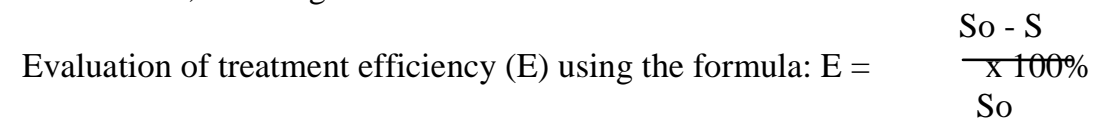

Description:

E : Efficiency

S : Final concentration (outlet)

So : Initial concentration (inlet)

The results were that the efficiency of the decrease in concentration of BOD at PT. SST $=99.58 \%$, PT. WTU $=$ $99.96 \%$ and PT. BIC $=99.73 \%$.

\subsubsection{Efficiency of Decrease in Concentration of Chemical Oxygen Demand (COD)}

Chemical Oxygen Demand is the amount of oxygen required to oxidize organic compounds in water, so COD parameter reflects the amount of organic compounds chemically oxidized. The measurement of COD values is indispensable to quantify organic matters in domestic waste water containing toxic elements for microorganisms. It can be seen from the table that COD concentration of the laboratory test results on the waste 
samples at the inlet and outlet of WWTP. From the analysis of BOD and COD in the laboratory, we can calculate the comparative figures of BOD and COD in the waste water. The comparative figures of BOD and COD show the possibility level of the waste water to be treated biologically. The comparative figure approaching (1) indicates that it can be treated biologically, while the figure close to zero (0) indicates not suitable.

Table 6. Efficiency of WWTP performance in plywood industries of PT. SST, PT. WTU and PT. BIC

\begin{tabular}{|c|c|c|c|c|c|c|}
\hline No & Industry & Parameter & $\begin{array}{l}\text { Concentration of } \\
\text { Inlet }(\mathrm{m} / \mathrm{l})\end{array}$ & $\begin{array}{c}\text { Concentration of } \\
\text { Outlet }(\mathrm{m} / \mathrm{l})\end{array}$ & Removal & Efficiency \\
\hline \multirow{5}{*}{1} & \multirow{5}{*}{ PT. SST } & $\mathrm{pH}$ & 7.81 & 7.8 & - & - \\
\hline & & TSS & 104 & 34 & 70 & 67.30 \\
\hline & & COD & 9887 & 38.45 & 9848.57 & 99.61 \\
\hline & & Ammoniac & 15.550 & 0.26 & $15,549.74$ & 99.99 \\
\hline & & Phenol & 6.17 & 0.16 & 6.01 & 90.41 \\
\hline \multirow{5}{*}{2} & \multirow{5}{*}{ PT. WTU } & TSS & 113 & 3.30 & \multirow{5}{*}{$\begin{array}{r}- \\
109.7 \\
17,332.65 \\
36802 \\
5099.92 \\
46.38\end{array}$} & 97.08 \\
\hline & & BOD & 17340 & 7.35 & & 99.96 \\
\hline & & COD & 36832 & 30 & & 99.92 \\
\hline & & Ammoniac & 5100 & 0.08 & & 99.99 \\
\hline & & Phenol & 46.63 & 0.25 & & 99.46 \\
\hline \multirow{4}{*}{3} & \multirow{3}{*}{ PT. BIC } & COD & 18700 & 52.13 & \multirow{4}{*}{$\begin{array}{r}- \\
210 \\
9275.4 \\
18647.87 \\
46899.85 \\
18.95 \\
\text { Average }\end{array}$} & 99.72 \\
\hline & & Ammoniac & 46900 & 0.15 & & 99.99 \\
\hline & & Phenol & 19.07 & 0.12 & & 99.37 \\
\hline & & & & & & 97.19 \\
\hline
\end{tabular}

Source : Field observation and lab analysis of Baristrand Banjarbaru in 2011 (results of analysis attached)

The biological treatment was performed by this formula:

$E=\frac{\text { So }-S}{\text { So }} \times 100 \%$

The efficiency of waste water treatment obtained on COD parameters:

$\begin{array}{ll}\text { PT. SST } & =99.61 \% \\ \text { PT. WTU } & =99.92 \%\end{array}$

PT. WTU $=99.92 \%$

PT. $\mathrm{BIC}=99.72 \%$

\subsubsection{Efficiency of Decrease in Total Suspended Solid (TSS)}

The concentration of TSS from the test in the laboratory, which was the sample of the wastewater at the inlet and outlet of WWTP, is showed in Table 7. The TSS concentration at the outlet already met the effluent quality standards for plywood industry.

TSS value was the content of suspended solids which affected the water turbidity of effluent which was the outcome of WWTP. The efficiency of waste water treatment on the parameters of TSS was:
PT. SST
$=67.30 \%$
PT. WTU
$=97.08 \%$

PT. $\mathrm{BIC}=87.73 \%$

The higher the percentage of efficiency, the better the coagulant process.

\subsection{Overview of Waste Load Removal Efficiency}

The evaluation of the building of a waste treatment unit is intended to find out the extent to which the effectiveness of treatment in order to generate the effluent which meets standards and efficiency of the treatment.

Waste Water Treatment Plant in plywood industry is the waste treatment using activated sludge system in the form of aeration pond. Activated sludge is a continuous process, where the populated biological growth will be mixed with waste water and then aerated continuously, followed by precipitation to separate the biological growth from the treated waste water. The advantages are : (a). There is not too much sludge generated due to sludge recirculation, (b). The operation is easy, not requiring too much space and (c). It is effective in reducing pollutant parameters in plywood industry. 
The drawbacks is : There is a little hard to plan the building because it needs calculations for biological growth and sludge recirculation.

The figures obtained from the analysis of waste water both at the inlet and at outlet indicated that the efficiency of the WWTP was quite high, where each indicator reached $67 \%$ to $99.99 \%$. The reuse of Hazardous and Toxic Waste must obtain a license from the Ministry of Environment (Based on the Decree of Environment Ministry No. 02 of 2008 on Use of Hazardous and Toxic Waste.

\section{Conclusions}

\section{Conclusions And Suggestion}

a. Water quality and liquid waste

The analysis results of liquid waste that went into the reservoirs in the three plywood industries showed the quality that was far worse (exceeding the threshold limit value) than it should be for plywood industry, even lower than the quality of water in Barito River and Martapura River, so when untreated the waste water would contaminate the river water. Therefore, the plywood industries carried out the treatment in WWTP (Waste Water Treatment Plant) so that the waste water discharged into the river environment would meet the threshold limit value. The evaluation of the waste water at the outlet, on the basis of the Regulation of South Kalimantan Governor No. 038 of 2008 on Liquid Waste Quality Standards, indicated that the waste water from the plywood industries was still met the quality standards (threshold limit values).

b. It can be seen from the figures obtained from the analysis of waste water at the inlet and outlet that the efficiency of the WWTP on each plywood industry was quite high. Each criterion and indicator reached $67 \%$ to $99.99 \%$

c. Quantitatively, the plywood industries produced liquid waste (discharge) $=68.4 \% \mathrm{~m}^{3} / \mathrm{month}$ on average. With an average production of $9,854.06 \mathrm{~m}^{3} /$ month, the ratio of liquid waste was $68.4 \mathrm{~m}^{3}: 9,854.06 \mathrm{~m}^{3}$ $=0.007 \mathrm{~m}^{3}$ per $\mathrm{m}^{3}$ of product. On the basis of the Decree of South Kalimantan Governor No. 036 of 2008, the maximum discharge is $0.30 \mathrm{~m}^{3} / \mathrm{m}^{3}$ of product to meet the quality standards.

d. The recirculation of sludge considered hazardous and toxic waste, and reusing (recycle) it must obtain the permission from Ministry of Environment.

\section{Suggestion}

In terms of utilization of sludge waste, a plywood industry must apply for a utilization permit on the basis of Regulation of the Minister of Environment No. 02 of 2008 on Use of Hazardous and Toxic Waste. In fact, by utilizing the sludge waste, industries implement the minimization of waste through recycling the sludge into filler (adhesive mixture), so it should not need permission but just need to report. It even should get a reward for suppressing and reducing the waste by recycling.

\section{References}

[1]. Anonim, 2010. Management and Environmental Utilization Efforts (UKL and UPL). Plywood Industry Operations of PT. Wijaya Tri Utama, Banjarmasin.

[2]. ICIP. Indonesian Cleaner Industrial Production. , 2004. A study on Net Production in Plywood Industry, Jakarta.

[3]. Kasmudjo. 1982. An Introduction to Plywood Industry, Foundation for Development of Forestry Faculty, University of Gajah Mada: 11-55. Yogyakarta.

[4]. Kris, P. 2002. Ecological Industry. ANDI: 155-227. Yogyakarta.

[5]. Manik, K.E.S. 2007. Environmental Management. Djambatan: 35 -51. Jakarta.

[6]. Manurung, T, et al, 2007. Roadmap of Indonesian Forestry Industry Revitalization. Ministry of Forestry. Jakarta.

[7]. Minarsih, T.H. 2006. Practical Guides of Environmental Management of Plywood Industry. Deputy Assistant. Field of AgroIndustrial Pollution Control. Jakarta.

[8]. $\quad$ Nasution, A.H. 2006. Industry Management. Publisher CV. Andi Offset. Yogyakarta.

[9]. Noer, E. 2006. Net Production, cooperation between Faculty of Math and Science IPB and Directorate General of Higher Education, Ministry of National Education, Cisarua.

[10]. Rahman. O. 1978. A Case Study on Waste In Making Plywood. Report No. 121. Institute of Forest Product Research, Agency for Researchers and Agricultural Development. Department of Agriculture. Bogor.

[11]. Sastrawyaya, AT. 2009. Environmental Pollution, Rineka Copyright: 53-64. Yogyakarta.

[12]. Sibarani. 1991. Identification of Waste from Plywood Processing Industry and Utilization Possibilities at PT Kayu Lapis Indonesia Semarang (Thesis). Faculty of Forestry, Bogor.

[13]. Soergani. M. 1997. Development and Environment: Pursuing Idea and Implementation of Sustainable Development. Institute of Education and Environmental Development. Jakarta.

[14]. Supardi. HI, 2003. Environment and Its Sustainability, Publisher PT. Alumni: 28-54. Bandung.

[15]. Haygreen, J.G. and J.J. Gowyer. 1982. Forest Product and Wood Science, an Introduction, the Iowa State University Press: 335 346 Wes Iowa

[16]. International Organization for Standardization (ISO) 1996. Environmental Management - Specification with Guidance for Use, Genewa ISO 14001.

[17]. United Nation Environment Programme (UNEP). 1991 Audit and Reduction Manual for Industrial Environment and Waste. Viena: UNEP IF/UNIDO 